\title{
TUBEROUS ORGANS IN UTRICULARIA, AND NEW OBSERVATIONS OF SUB-TUBEROUS STOLONS ON UTRICULARIA RADIATA SMALL
}

\section{BARRY RICE •P.O. Box $72741 •$ Davis, CA 95617 •USA •barry@sarracenia.com}

Keywords: observations: Texas, U tricularia radiata, U tricularia inflata-physiology: U tricularia radiata.

The genus U tricularia is confounding and bizarre. You are simply wrong if you think that the genus can be dismissed as a set of freefloating lake weeds, or stringy terrestrial species with tiny leaves. Many of its species produce mysterious, strange structures; the diversity of pecul iar things exhibited by U tricularia species astonishes.

The production of tubers is such an example - nearly twenty species of $U$ tricularia areknown to generate them (Plant physiologists might argue whether all these structures are truly tubers in the technical sense.) The species that produce tubers are not particularly closely related to each other; Taylor (1989) notes that they occur in six separatesections (A ranella, C helidon, O rchidioides, P hyllaria, Pleiochasia, U tricularia).

Despite this diversity, U tricularia tubers can probably be divided into two main types. Tubers of the first type function as water storage reservoirs. Consi der species in the section 0 rchidioidesmany of these plants are epiphytes that live on trees, and rely upon thesmall amount of moisture that unreliably trickles down the branches. Dehydration is a significant risk, so water-storing tubers are a good insurance policy for survival. Storing carbohydrates (i.e., food) is probably only a secondary function for these tubers.

Section Orchidioides is known for its horticulturally finicky members. But it is equally well known that, if cajoled into survival, these plants reward the grower with spectacular flowers. U tricularia alpina is the species most likely to be cultivated (Wyman 2008), but other species such as U. jamesoniana arefairly easy to grow. In horticulture, 0 rchidioides tubers are not useful in propagation, al though exploring this further might be an enlightening and productive field of research.

The second type of $U$ tricularia tuber consists of those that function as a carbohydrate reserve. The best-known example of this is U tricularia menzi esi i, which is dormant during thelong, hot, dry summers of its native southwestern Australia. Each fall it emerges from dormancy, powered by the energy resources stored in its cluster of carbohydrate-rich tubers at the inflorescence base. For the horticul turist, these tubers provide a convenient way to ship plants during dormancy. Furthermore, by judi ciously separating the tubers, plants can readily be propagated.

These two types of U tricularia tubers occur in many forms. Frequently, as in the epiphytic U tricularia, they are loosely clustered near the bases of inflorescences. But this is certainly not the only model for tubers in the genus! In $\mathrm{U}$. brachiata, only a single tuber is produced by the plant, and it is located directly under the flower stalk. U tricularia christopheri also produces a singletuber, but it is located a little deeper in the soil-it is attached to the rosette by a little shoot. This is similar to the $G$ enlisea pygmaea tubers observed by Rivadavia (2007). U tricularia mannii has a single basal tuber, but it al so produces smaller ones on its stolons. Probably my favorite of the group, the peculiar U. moniliformis, has multiple tubers strung together on the stolons like sausages on a string! 


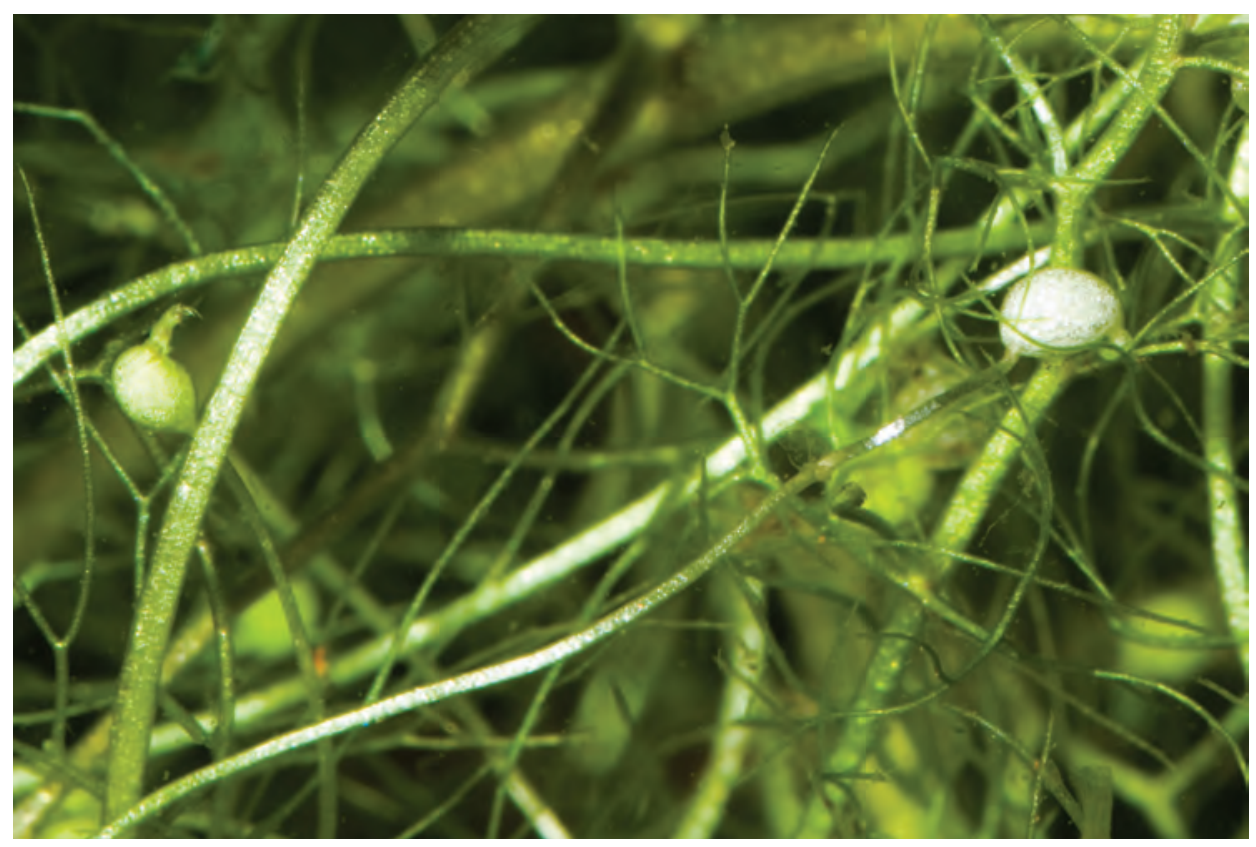

Figure 1: Utricularia inflata tubers on long, strand-like shoots. The tuber at far left has extruded a new growth.

The familiar U tricularia inflata also produces carbohydrate-rich tubers, although they are only a few mm in diameter (see Figure 1). U tricularia inflata is in the genus section U tricularia, which incl udes the most common aquatic or semi-aquatic species such as U. austral is, U. gibba, U. macrorhiza, and U. vulgar is. (The related U. platensis al so generates tubers.) Tubers can usual ly befound on large $U$. inflata plants, and their presence is a useful way to distinguish it from similar species (such as U. macrorhiza). Supposedly, being stranded on mud is particularly conducive to encouraging U. inflata plants to producetubers (Taylor 1989). But why the plant produces its tubers on whiplikeshoots, several cmlong, defies easy explanation!

InApril 2006, I visited eastern Texas and was led on fascinating trips to several carnivorous plant sites by Mike Howlett and Michael Pagoulatos (Rice 2006). Our trips were focusing on Sarracenia alata, Pinguicula pumila, and U tricularia purpurea, but there were many other things of interest to see. One Harris County site that Mike promised to show me boasted a plant that he claimed was U tricularia radiata. This was surprising to me, sinceTayl or (1989) did not record thespecies in Texas.

Unfortunately, it had been a dry year and upon our arrival we saw that the water levels at the U tricularia radiata site were lower than optimal. Standing on the edge of the muddy wetland we could not see any carnivorous plants at all-it certainly was not choked with U tricularia. Still, we were there, so we careful ly expl ored the muck and after much poking around, wefound a few shoots embedded in the mud. The specimens were pathetic - short stolon fragments a decimeter or so long. Most did not even have leaves, but the few leaves that were present showed the very regular dichotomous branching that is characteristic of $U$. radiata. Clearly, Mike's dubi ous claims were vindicated. (I have since seen herbarium specimens of $U$. radiata from other Texan sites.)

In my experience, U. radiata usual ly grows as an annual, so I surmised that the plants we were seeing were in their death throes. However, as I extricated lengths of stolon from the mud, I was 


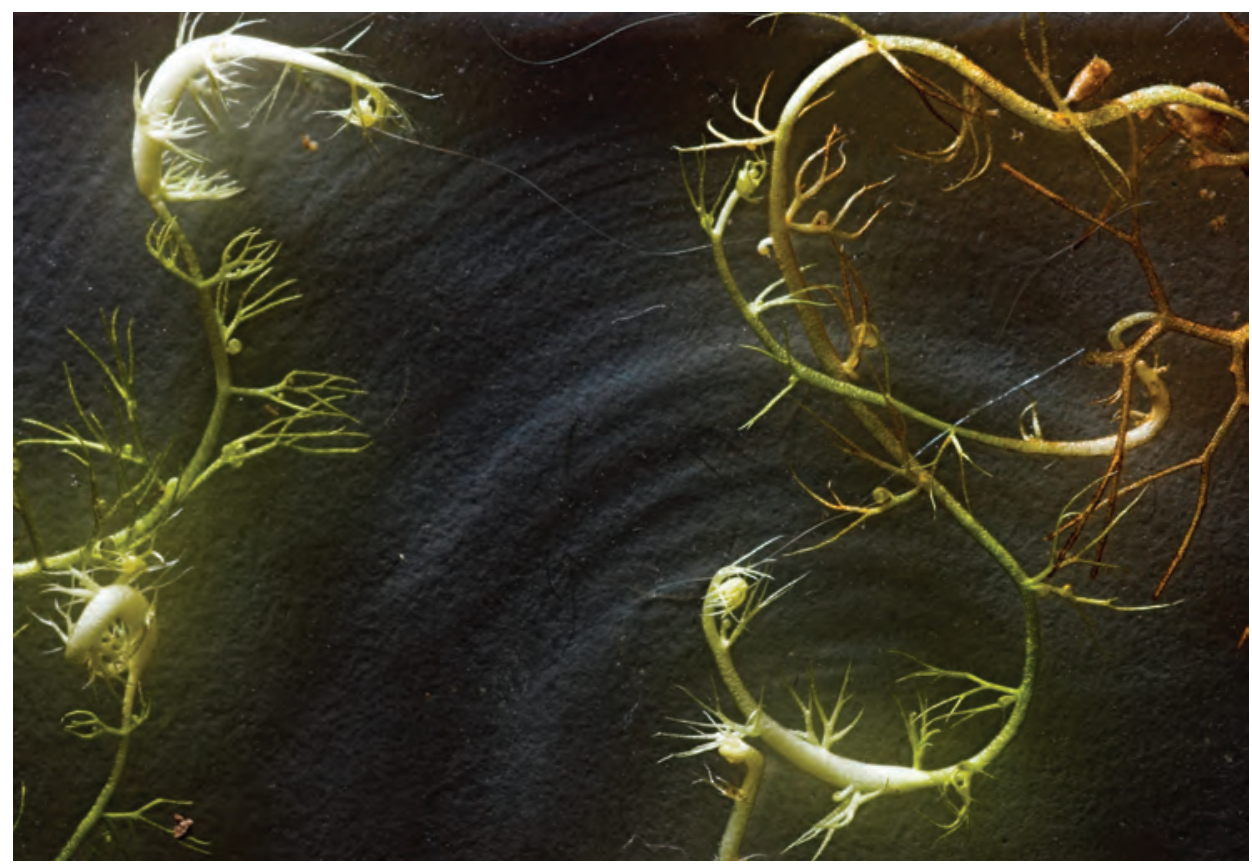

Figure 2: Utricularia radiata shoots with swollen, sub-tuberous, chlorophyll-free segments.

surprised to see that intermittent lengths of the shoot were swollen, and lacking in chlorophyll (see Figure 2). Unlike the flexible, green parts of the shoots, these swollen lengths were stiff and, when broken, were clearly supplemented by starchy tissues. Quite frequently, the swollen stolons were twisted around in small loops, al most knot-like in character (see Figure 3).

I do not know of these structures having been observed before. I can only surmise that they were produced by the $U$ tricularia radiata plants in response to the temporarily inhospitable conditions of the season. So not only was I surprised to learn that $U$. radiata occurred in Texas, we were both surprised to discover that it probably grows as a perennial, and a sub-tuberous one at that!

As there were not many plants at the site, I took only a few small fragments with me to photograph. Remarkably, after only 48 hours at room conditions, the knot-like loops straightened, the tuberous shoots lengthened and developed chlorophyll, and leaves started to form. Truly, these sub-tuberous shoots were powerful energy sources! Unfortunately, I was unable to provide suitable growing conditions rapidly enough and the plants perished. However, strains of U. radiata such as at these Texas sites have potential for the specialist horticulturists who might find the usual, annual nature of the species to befrustrating.

Acknowledgements and notes: I would like to thank Mike Howlett in particular for his kindly provided guidance as we travel ed through Texas together. No permits were required to visit or collect material from the site described in this paper.

\section{References}

Rice, B. 2006. Carnivorous plant FAQ field trip report: Travels with Booger. http://www.sarracenia. com/trips/tx012006.html. Accessed May 2010. 


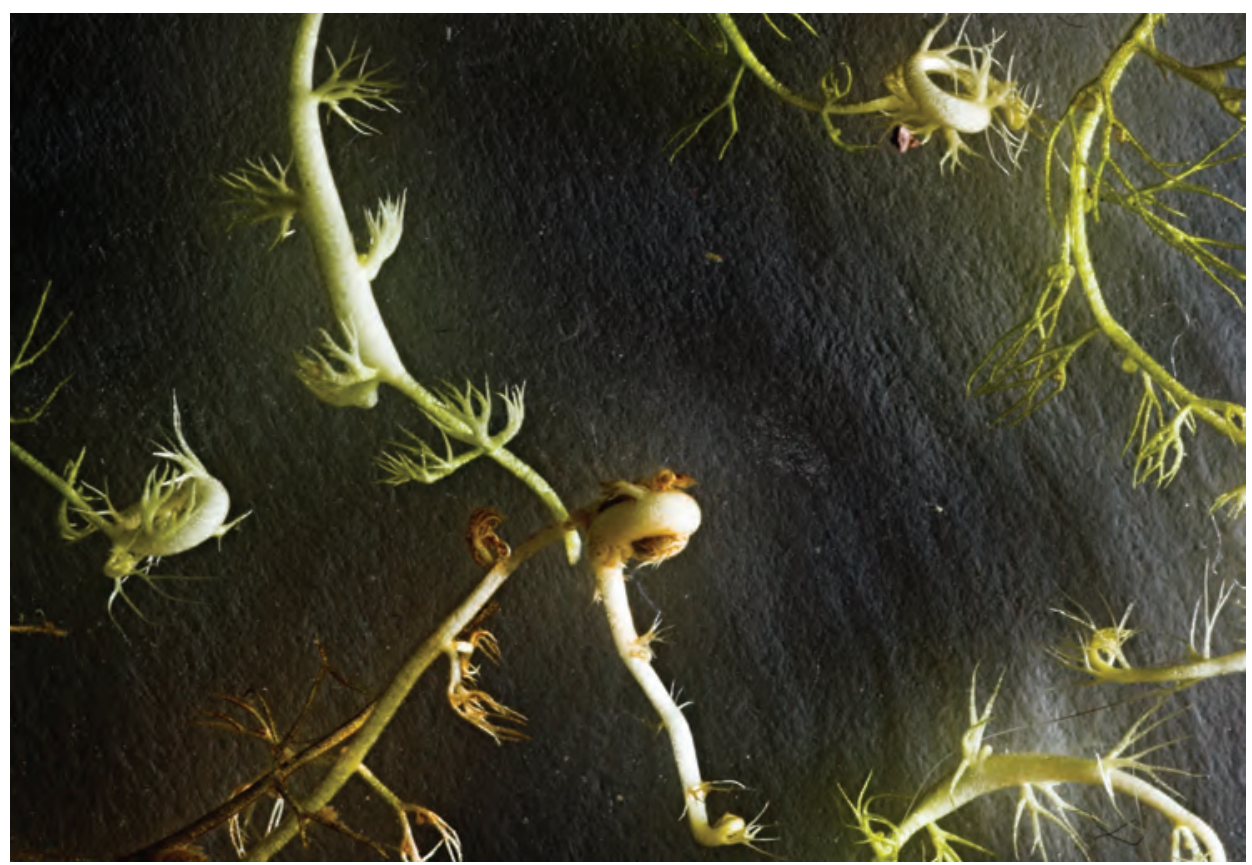

Figure 3: Utricularia radiata shoots with swollen sub-tuberous organs, twisted into short loops. The loops at top right and middle-left are starting to uncurl.

Rivadavia, F. 2007. A G enlisea myth is confirmed. Carniv. PI. Newslett. 36: 122-125.

Taylor, P. 1989. TheGenus U tricularia - a taxonomic monograph. Kew Bull. Additional Series XIV. HMSO. London.

Wyman, T.H. 2008. On growing U tricularia sect. Orchidioides. Carniv. PI. Newslet. 37: 68-74.

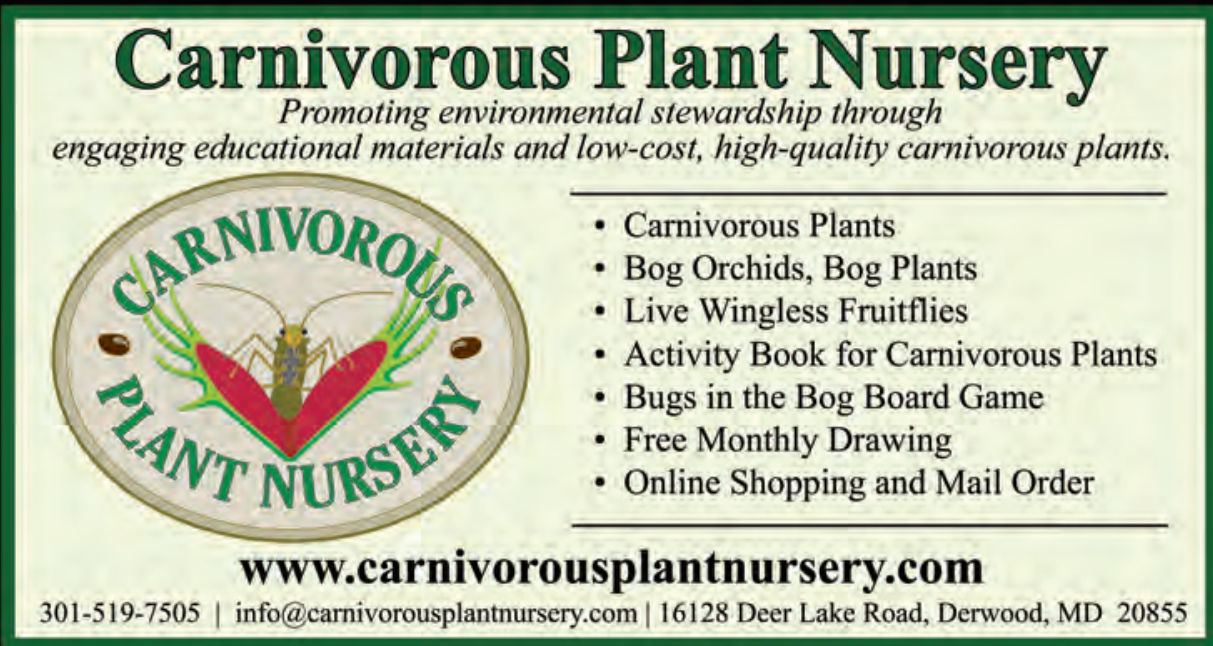

